\title{
Surveillance for zoonotic and selected pathogens in harbor seals Phoca vitulina from central California
}

\author{
Denise J. Greig ${ }^{1,9, *}$, Frances M. D. Gulland ${ }^{2}$, Woutrina A. Smith ${ }^{3}$, \\ Patricia A. Conrad ${ }^{3}$, Cara L. Field ${ }^{4}$, Michelle Fleetwood ${ }^{5}$, James T. Harvey ${ }^{6}$, Hon S. Ip $^{7}$, \\ Spencer Jang ${ }^{8}$, Andrea Packham ${ }^{3}$, Elizabeth Wheeler ${ }^{2}$, Ailsa J. Hall ${ }^{1}$ \\ ${ }^{1}$ Sea Mammal Research Unit, Scottish Oceans Institute, University of St Andrews, St Andrews KY16 8LB, UK \\ ${ }^{2}$ The Marine Mammal Center, Sausalito, California 94965, USA \\ ${ }^{3}$ Department of Pathology, Microbiology, and Immunology, School of Veterinary Medicine, University of California, Davis, \\ California 95616, USA \\ ${ }^{4}$ Mystic Aquarium \& Institute for Exploration, Mystic, Connecticut 06355, USA \\ ${ }^{5}$ New Hampshire Veterinary Diagnostic Laboratory, University of New Hampshire, Durham, New Hampshire 03824, USA \\ ${ }^{6}$ Moss Landing Marine Laboratories, Moss Landing, California 95039, USA \\ ${ }^{7}$ US Geological Survey, National Wildlife Health Center, Madison, Wisconsin 53711, USA \\ ${ }^{8}$ William R. Pritchard Veterinary Medical Teaching Hospital, School of Veterinary Medicine, University of California, Davis, \\ California 95616, USA \\ ${ }^{9}$ Present address: The Marine Mammal Center, Sausalito, California 94965, USA
}

\begin{abstract}
The infection status of harbor seals Phoca vitulina in central California, USA, was evaluated through broad surveillance for pathogens in stranded and wild-caught animals from 2001 to 2008, with most samples collected in 2007 and 2008. Stranded animals from Mendocino County to San Luis Obispo County were sampled at a rehabilitation facility: The Marine Mammal Center (TMMC, $\mathrm{n}=175$ ); wild-caught animals were sampled at 2 locations: San Francisco Bay (SF, $\mathrm{n}=78$ ) and Tomales Bay (TB, $\mathrm{n}=97)$, that differed in degree of urbanization. Low prevalences of Salmonella, Campylobacter, Giardia, and Cryptosporidium were detected in the feces of stranded and wild-caught seals. Clostridium perfringens and Escherichia coli were more prevalent in the feces of stranded (58\% [78 out of 135] and 76\% [102 out of 135]) than wild-caught (42\% [45 out of 106 ] and $66 \%$ [ 68 out of 106]) seals, whereas Vibrio spp. were 16 times more likely to be cultured from the feces of seals from SF than TB or TMMC ( $<<0.005)$. Brucella DNA was detected in $3.4 \%$ of dead stranded harbor seals (2 out of 58). Type A influenza was isolated from feces of 1 out of 96 wild-caught seals. Exposure to Toxoplasma gondii, Sarcocystis neurona, and type A influenza was only detected in the wild-caught harbor seals (post-weaning age classes), whereas antibody titers to Leptospira spp. were detected in stranded and wild-caught seals. No stranded $(\mathrm{n}=109)$ or wildcaught $(\mathrm{n}=217)$ harbor seals had antibodies to phocine distemper virus, although a single low titer to canine distemper virus was detected. These results highlight the role of harbor seals as sentinel species for zoonotic and terrestrial pathogens in the marine environment.
\end{abstract}

KEY WORDS: Campylobacter - Leptospira - Influenza $\cdot$ Morbillivirus $\cdot$ Neospora $\cdot$ Sarcocystis Toxoplasma $\cdot$ Vibrio

Resale or republication not permitted without written consent of the publisher

\section{INTRODUCTION}

Infectious disease outbreaks have been reported in marine mammals worldwide (Gulland \& Hall 2007) with some having serious impacts on marine mammal populations. In 1988, for example, approximately
18000 harbor seals Phoca vitulina died from phocine distemper virus (PDV) in the North Sea (Heide-Jorgensen et al. 1992) and thousands of Baikal seals $P$. sibirica died from canine distemper virus (CDV, Mamaev et al. 1996). In addition to the disease risks to marine mammal populations, many diseases that 
affect marine mammals are zoonoses, raising concerns that marine mammal excretions may pose a risk to human health (Knap et al. 2002). Human exposure by fecal, oral, or respiratory routes could occur in the water, on docks, boats, or beaches, or through occupational health exposure.

Zoonotic pathogens known to cause disease in harbor seals include influenza A (Geraci et al. 1982, Anthony et al. 2012), Brucella (Garner et al. 1997), Toxoplasma gondii (Lapointe et al. 1998, Miller et al. 2001), and Leptospira interrogans (Stamper et al. 1998, Stevens et al. 1999). Surveys of apparently healthy seals in remote areas considered to be relatively pristine have demonstrated exposure to zoonotic bacteria such as Brucella spp., and protozoa such as Giardia, T. gondii, and Sarcocystis neurona (Olson et al. 1997, Dubey et al. 2003, Zarnke et al. 2006, Jensen et al. 2010), highlighting the role that marine mammals may play both as sentinels of pathogen pollution in the marine environment and as potential reservoirs for pathogens that could affect humans (Ross 2000). There are thus a variety of zoonotic organisms in the marine environment that can impact both marine mammal and human health. In coastal California, USA, harbor seals share habitats with humans, with some habitats clearly impacted by human development through sewage outfalls and run-off from urban and agricultural land uses (Grigg et al. 2004).

The objectives of this study were (1) to assess the risks to wild harbor seals in central California from pathogens known to cause disease in this species, and (2) to assess the use of harbor seals as sentinels of zoonotic pathogen pollution of the near shore coastal environment. Specific pathogen screening focused on Escherichia coli, Clostridium perfringens, Vibrio spp., Campylobacter spp., Salmonella spp., Giardia duodenalis, Cryptospordium spp., Brucella spp., type A influenza virus, Leptospira spp., T. gondii, S. neurona, Neospora caninum, PDV and CDV.

\section{MATERIALS AND METHODS}

\section{Sampling}

In 2007 and 2008, exposure to infectious pathogens was determined in harbor seals brought to a seal rehabilitation hospital (The Marine Mammal Center, TMMC) and in harbor seals captured and released (Jeffries et al. 1993) at 2 locations: Castro Rocks in San Francisco Bay (SF, 37 $55^{\prime} 58^{\prime \prime} \mathrm{N}, 122^{\circ} 25^{\prime} 3^{\prime} \mathrm{W}$ ) and Tomales Bay (TB, 38 $13^{\prime} 9^{\prime \prime} \mathrm{N}, 122^{\circ} 57^{\prime} 42^{\prime} \mathrm{W}$; Fig. 1). All animal handling was conducted under

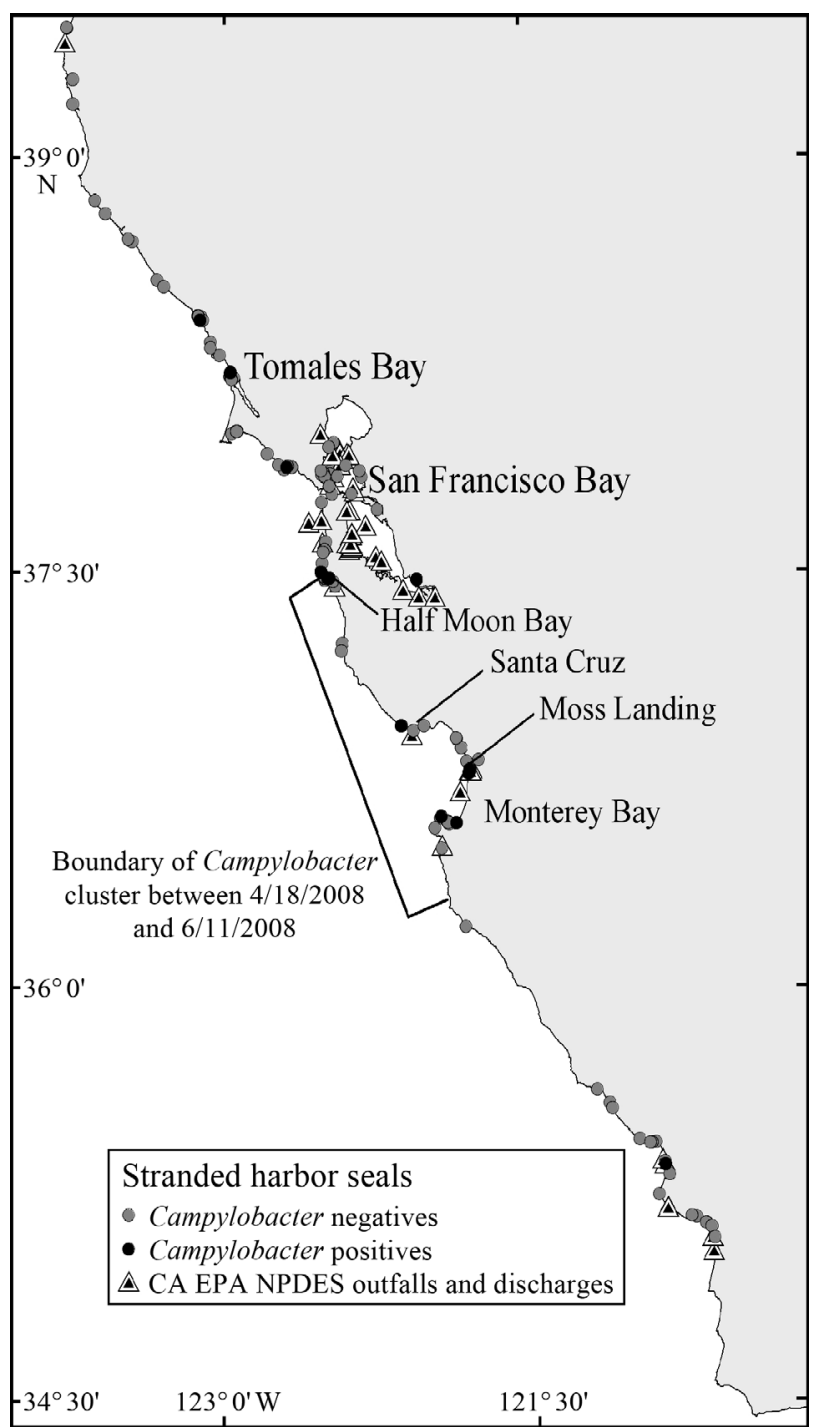

Fig. 1. Stranding locations (circles) of harbor seals sampled for fecal pathogens in 2007 and 2008 in California, USA. Major outfalls and discharge locations are identified by the California Environmental Protection Agency's National Pollutant Discharge Elimination System (CA EPA NPDES, triangles). Campylobacter positive (black circles) and negative (gray circles) sample results are shown based on culture of fecal swabs. Dates are given as $\mathrm{mm} / \mathrm{dd} /$ yyyy

MMPA permit numbers 932-1905-00/MA-009526, 555-1870-00, and 373-1868-00. At the time of admission or capture, seals were weighed, measured (length and girth), and had a blood sample drawn. Seals were assigned to an age class based on mass, time of year, and stage of development (Bigg 1969, Dierauf et al. 1986, Greig 2002): pup (0 to $\sim 4 \mathrm{wk}$ ), weaned pup ( 4 wk to $1 \mathrm{yr})$, yearling (1 to $2 \mathrm{yr}$ ), subadult ( $2 \mathrm{yr}$ to $45 \mathrm{~kg}$ ), adult ( $>45 \mathrm{~kg}$ ). Blood was centrifuged and serum archived at $-80^{\circ} \mathrm{C}$ for serologic testing. Three rectal swabs were collected from 
each animal for the detection of fecal bacteria, placed into Cary Blair transport media (Becton Dickinson) and refrigerated at $4^{\circ} \mathrm{C}$ for less than $24 \mathrm{~h}$ until overnight shipment to the microbiology lab. When available, a fecal sample was collected with a fecal loop and stored at $4^{\circ} \mathrm{C}$ for the detection of Giardia and Cryptosporidium. A nasal and rectal swab from each wild-caught harbor seal was placed into viral transport media (as described in Ip et al. 2008) and frozen at $-80^{\circ} \mathrm{C}$ for type A influenza virus testing. A complete necropsy including collection of tissues for histopathology was performed at TMMC on stranded seals that died. Spleen and tracheobronchial lymph node samples were frozen at $-80^{\circ} \mathrm{C}$ for Brucella spp. testing. Archived serum samples collected from wildcaught harbor seals in 2001, 2002, 2004, 2005 and 2006 were available for serology, and additional swabs for fecal bacteria were collected in 2006. Archived sera from 2004 through 2006 were not analyzed until 2008; these sera were maintained at $-80^{\circ} \mathrm{C}$ with no freeze-thaw cycles.

\section{Sample analysis}

\section{Fecal bacteria}

Rectal swabs were plated onto selective media, and bacteria that grew were identified using standard microbiological techniques (Murray et al. 2003). Salmonella isolates were identified to serogroup (B, C1, D, E) by their agglutination to Salmonella anti-sera (Fisher Scientific) and to strain with additional agglutination tests performed at the National Veterinary Services Lab (NVSL) in Ames, Iowa. Potential Campylobacter colonies that grew on a Campylobacter agar containing cefoperazone, vancomycin, and amphotericin B were stained with BBL Gram stain reagents (Fisher Scientific) to check their morphology. Selected colonies were then subcultured to blood agar. Disks impregnated with nalidixic acid and cephalothin were placed on the inoculated blood agar plate and incubated for $48 \mathrm{~h}$. The sensitivity pattern of the isolate to the antibiotic disks was recorded, and further testing for confirmation included a catalase test (Hardy Diagnostics) and a hippurate disk test (Hardy Diagnostics). Vibrio colonies were identified to species using API 20E strips (bioMérieux). Clostridium perfringens was identified by its characteristic reaction to egg yolk agar (lecithinase production), the Christie Atkins Munch-Petersen (CAMP) test, indole reaction, aerotolerance, and typical Gram stain morphology.

\section{Giardia and Cryptosporidium}

In 2006 and 2007, fecal samples were examined for Giardia spp. cysts and Cryptosporidium spp. oocysts using a direct immunofluorescent antibody test (DFA, A100FLK Aqua-Glo G/C Direct Comprehensive Kit from Waterborne). Up to $5 \mathrm{~g}$ feces per sample were washed with dilute dish-washing detergent and strained through gauze into a $50 \mathrm{ml}$ conical vial, followed by centrifugation for $10 \mathrm{~min}$ at 1000 to $1500 \mathrm{~g}$. The top layer of the pellet was then transferred to a DFA slide well using a 10UL fecal loop (Fisher Scientific). Slides were dried and kept up to 2 wk before incubating with fluorescent antibody and viewing with a fluorescent microscope. Microscopy positive slides were scraped with a scalpel blade for DNA extraction and PCR amplification of 18S protozoal genotype sequences (Morgan et al. 1997). In 2008, fecal samples were sent to Wood's Hole Oceanographic Institution, Wood's Hole, Massachusetts for direct PCR detection of G. duodenalis DNA (Lasek-Nesselquist et al. 2010).

\section{Type A influenza virus}

Nasal and rectal swabs were submitted to the National Wildlife Health Center for detection of all subtypes (H1-H16) of type A influenza recognized at the time of testing using real-time PCR (RT-PCR) (Ip et al. 2008). After RNA extraction, a 1-step RTPCR kit (Qiagen) was used with a PCR primer set designed for a region conserved in all type $A$ influenza virus Matrix genes (Spackman et al. 2002). Viral isolation in embryonating eggs was attempted from all 2008 samples. Allantoic fluids from each egg were tested for the presence of hemagglutinating viruses using chicken and turkey red blood cells, and possible influenza isolates were re-tested by RT-PCR and partial genome sequencing (Ip et al. 2008).

Sera for the detection of antibodies to avian influenza virus were submitted to the Southeastern Cooperative Wildlife Disease Study at the University of Georgia in Athens, Georgia. Testing was performed using a commercially available blocking enzyme-linked immunosorbent assay (bELISA, FlockCheck AI MultiS-Screen antibody test kit, Idexx Laboratories) that was validated for use in avian and mammal species (Brown et al. 2009, Ciacci-Zanella et al. 2010). The test was performed and interpreted according to the manufacturer's instructions as described in Brown et al. (2009). The 
test was validated for mammals using sera from influenza-infected ferrets as a mammalian control. Serum samples with a result-to-negative-control (S/N) absorbance ratio greater than or equal to 0.50 were considered negative for the presence of avian influenza virus antibodies, and samples with $\mathrm{S} / \mathrm{N}$ values less than 0.50 were considered positive (Brown et al. 2009).

\section{Brucella}

Samples of spleen and tracheobronchial lymph node from dead stranded harbor seals were submitted to Mystic Aquarium and Institute for Exploration, Mystic, Connecticut, for PCR amplification of Brucella spp. DNA. Nucleic acids were extracted from tissues using a standard tissue extraction kit (DNeasy, Qiagen). Quantitative PCR (qPCR) was performed on samples using the technique described by Sidor et al. (2013). Briefly, a multiplex qPCR assay was developed using a TaqMan probe-based assay which targets a 150 base pair amplicon from bcsp31, an outer membrane protein gene specific to the Brucella genus. The triplex assay includes 2 internal controls for DNA quality and to detect endogenous inhibitors of PCR. Evaluation of this assay using a variety of common aquatic bacterial isolates demonstrated $100 \%$ specificity for Brucella, and assays of DNA extracted from pinniped and cetacean origin Brucella isolates demonstrate sensitivity at or below 3 bacteria. RT-PCR was then performed on samples using the Light Cycler 2.0 instrument (Roche Diagnostics), with an initial 15 min denaturation step at $95^{\circ} \mathrm{C}$, followed by 45 cycles of $95^{\circ} \mathrm{C}$ denaturation for $30 \mathrm{~s}$ and $63^{\circ} \mathrm{C}$ annealing/extension for $60 \mathrm{~s}$, with a final cooling step at $40^{\circ} \mathrm{C}$ for $60 \mathrm{~s}$. Each sample was run in triplicate and a reagent blank, negative tissue control, and positive bacterial dilutions were run in each batch of samples tested.

\section{Leptospira}

Serum samples were tested for antibodies against 5 serovars and 1 serogroup of Leptospira interrogans (serovar Bratislava, serovar Canicola, serovar Grippotyphosa, serovar Hardjo, serogroup Icterohemorrhagiae, and serovar Pomona) by the California Animal Health and Food Safety Laboratory in Davis, California, using the microscopic agglutination test (MAT; Cole Jr et al. 1973). Although it has not been validated for harbor seals, the Leptospira MAT has been validated for the California sea lion Zalophus californianus with titers of 1:100 and greater considered positive for exposure (Colagross-Schouten et al. 2002).

\section{Toxoplasma gondii, Sarcocystis neurona, and Neospora caninum}

An indirect fluorescent antibody test (IFAT) was used to detect antibodies to T. gondii, S. neurona, and N. caninum as described by Miller et al. (2001). Briefly, serially diluted serum was applied to prepared 12-well antigen slides and incubated. Fluorescein isothiocyanate conjugated dog antibody at 1:100 dilution in phosphate buffered saline (PBS) was added to each well $(10 \mu \mathrm{l})$ and incubated a second time. Slides were then examined at $200 \times$ using a fluorescence microscope, and the last well with distinctly fluorescent parasite outlines was the reported titer. The T. gondii IFAT has not been validated for harbor seals, but has been validated for sea otters Enhydra lutris with confirmed active brain infections at a titer of 1:320 (Miller et al. 2002).

\section{Morbillivirus}

A virus neutralization test was used to detect antibodies to PDV and CDV. Serum samples collected in 2001 and 2002 were submitted to the Oklahoma Animal Disease and Diagnostic Laboratory, Stillwater, Oklahoma, in 2002, and samples collected 2004 through 2008 were submitted to the Athens Veterinary Diagnostic Laboratory at the University of Georgia in 2008. At both laboratories, the test was conducted according to methods described in Saliki \& Lehenbauer (2001). Antibody titers were expressed as the highest dilutions of sera that neutralized specific cytopathic effects in duplicate wells. Samples with a titer of 1:8 or greater were considered positive for morbillivirus antibody, and the virus against which the serum had the highest titer was considered to be the homologous virus (Saliki \& Lehenbauer 2001).

\section{Data analysis}

To evaluate whether pathogenic fecal bacteria were more likely to occur in stranded seals versus wild-caught seals, odds ratios were used to compare the probability of culturing fecal bacteria from seals in 3 groups: TMMC, SF and TB. Chi-square tests 
were used to compare antibody prevalence between groups. Odds ratio and chi-square analyses were performed using the $\mathrm{R}$ programming language ( $\mathrm{R}$ Development Core Team 2009).

Likelihood ratios calculated using $\operatorname{SaTS} \operatorname{can}^{\mathrm{TM}}$ v.8.0 (Kulldorff 2009) were used to determine whether there were any patterns in space and time among the distribution of Campylobacter cases compared to the seals that stranded without Campylobacter. Three likelihood ratios, the space-time scan statistic, the temporal scan statistic, and the spatial scan statistic were used with the Bernoulli model to test whether Campylobacter positives were randomly distributed in time and throughout the stranding response area (Kulldorff \& Nagarwalla 1995). SaTScan used Monte Carlo simulations to obtain the probability distributions of scan windows of different sizes to find the most probable clusters of cases compared with controls (Kulldorff 1997). Binary logistic regression analysis was used to test whether Campylobacter positives were associated with distance to major water outfalls and discharges, as classified by the California Environmental Protec- tion Agency's National Pollutant Discharge Elimination System (CA EPA NPDES).

\section{RESULTS}

The harbor seals admitted to TMMC from 2007 and 2008 ( $\mathrm{n}=175$ ) were primarily young-of-the-year seals, including pups likely separated from or abandoned by their mothers at birth $(\mathrm{n}=130)$, weaned pups ( $\mathrm{n}=28)$, yearlings $(\mathrm{n}=4)$, subadults $(\mathrm{n}=2)$, and adults $(\mathrm{n}=11)$. Wild-caught harbor seals captured from 2004 through 2008 ( $n=175)$ were a mixture of weaned pups ( $\mathrm{n}=46)$, yearlings $(\mathrm{n}=20)$, subadults $(\mathrm{n}=37)$, and adults $(\mathrm{n}=72)$. Wild-caught seals were in good body condition and appeared healthy at the time of capture. Not every seal was tested for every pathogen due to logistical constraints, and because different samples were collected from live and dead seals and used different pathogen detection methods (Table 1). Pathogen specific sample sizes and overall prevalence of exposure from each location (SF, TB, and TMMC) are summarized in Table 1, while age

Table 1. Sample tested, pathogen detection method, sample source, and sample size (percent positive) of each pathogen tested in stranded (dead or alive) harbor seals, either upon arrival at admission to The Marine Mammal Center (TMMC) or at necropsy, or sampled alive in the wild in San Francisco and Tomales Bays, California, USA. DFA: direct immunofluorescent antibody test; PCR: polymerase chain reaction amplification and DNA detection; ELISA: enzyme linked immunosorbent assay; MAT: microscopic agglutination test; IFAT: indirect fluorescent antibody test; VNT: virus neutralization test. Some animals sampled during necropsy spent time in rehabilitation prior to sampling (mean $=5 \mathrm{~d}$, range $=0$ to $70 \mathrm{~d}$ ). Note: wild-caught seals were post-weaning age classes while the majority of the stranded seals were pre-weaned. Seropositivity was assigned to

Leptospira interrogans titers $\geq 1: 100$ and Toxoplasma gondii, Sarcocystis neurona, and Neospora caninum titers $>1: 160$

\begin{tabular}{|c|c|c|c|c|c|c|}
\hline Pathogen & Sample & $\begin{array}{c}\text { Detection } \\
\text { method }\end{array}$ & Source & $\begin{array}{c}\text { San Francisco } \\
\mathrm{n}(\%)\end{array}$ & $\begin{array}{c}\text { Tomales Bay } \\
\text { n (\%) }\end{array}$ & $\begin{array}{l}\text { TMMC } \\
\mathrm{n}(\%)\end{array}$ \\
\hline \multicolumn{7}{|l|}{ Bacteria } \\
\hline Escherichia coli & Fecal swab & Culture & Wild, stranded & 45 (51.1) & $61(72.1)$ & $135(75.6)$ \\
\hline Clostridium perfringens & Fecal swab & Culture & Wild, stranded & $45(34.0)$ & $61(47.5)$ & $135(57.8)$ \\
\hline Vibrio spp. & Fecal swab & Culture & Wild, stranded & $45(60.0)$ & $61(8.2)$ & $135(12.6)$ \\
\hline Campylobacter spp. & Fecal swab & Culture & Wild, stranded & $45(10.6)$ & $61(6.6)$ & $135(9.6)$ \\
\hline Salmonella spp. & Fecal swab & Culture & Wild, stranded & $45(0.0)$ & $61(1.6)$ & $135(0.7)$ \\
\hline Brucella spp. & Spleen, lymph node & PCR & Stranded (necropsy) & 0 & 0 & $58(3.4)$ \\
\hline $\begin{array}{l}\text { Leptospira interrogans sero- } \\
\text { group Icterohemorrhagiae }\end{array}$ & Serum & MAT & Wild, stranded & $75(53.3)$ & $95(64.2)$ & $93(29.0)$ \\
\hline \multicolumn{7}{|l|}{ Viruses } \\
\hline Avian influenza & Serum & ELISA & Wild, stranded & $32(0.0)$ & $60(10.0)$ & 0 \\
\hline Type A influenza & Nasal/rectal swabs & PCR & Wild, stranded & $35(0.0)$ & $61(1.6)$ & $11(0.0)$ \\
\hline Canine distemper & Serum & VNT & Wild, stranded & $122(0.0)$ & $95(1.0)$ & $109(0.0)$ \\
\hline Phocine distemper & Serum & VNT & Wild, stranded & $122(0.0)$ & $95(0.0)$ & $109(0.0)$ \\
\hline \multicolumn{7}{|l|}{ Protozoa } \\
\hline Cryptosporidium spp. & Feces & DFA & Wild, stranded & $13(0.0)$ & $7(0.0)$ & $40(2.5)$ \\
\hline Giardia spp. & Feces & DFA & Wild, stranded & $13(7.7)$ & $7(14.2)$ & $40(0.0)$ \\
\hline Giardia duodenalis & Feces & PCR & Wild, stranded & $3(0)$ & $12(8.3)$ & $71(5.6)$ \\
\hline Neospora caninum & Serum & IFAT & Wild, stranded & $75(12.0)$ & $97(3.1)$ & $111(0.9)$ \\
\hline Sarcocystis neurona & Serum & IFAT & Wild, stranded & $75(6.7)$ & $97(11.3)$ & $111(0.9)$ \\
\hline Toxoplasma gondii & Serum & IFAT & Wild, stranded & $75(8.0)$ & $97(7.2)$ & $111(0.9)$ \\
\hline
\end{tabular}


class and comparisons among locations are discussed by pathogen in the following sections.

\section{Fecal bacteria}

Fecal swabs were collected from 243 harbor seals (135 stranded seals at admission to rehabilitation, 45 wild-caught in SF, and 61 wild-caught in TB). Escherichia coli was the most prevalent bacteria cultured in fecal samples from all 3 locations, followed by Vibrio parahemolyticus in SF samples and Clostridium perfringens in TMMC and TB samples (Table 1). E. coli was cultured from $75.6 \%$ of the stranded harbor seals, with stranded animals 2.7 times more likely to have $E$. coli cultured from their feces than wild-caught harbor seals (Table 2). C. perfringens was 2.5 times more likely in stranded harbor seals than the wild-caught seals. Hemolytic E. coli was present in all 3 groups of animals, but was 6 times more likely in harbor seals caught in SF than in either TB or stranded seals brought to TMMC. Campylobacter spp. were cultured from all 3 groups, but $C$. jejuni and $C$. coli were each only cultured from a single stranded animal. The remaining 11 Campylobacter cultures could not be typed without molecular methods but were determined not to be $C$. jejuni based on phenotypic characteristics. Vibrio spp. were 15.9 times more likely to be cultured from seals in SF largely driven by the high prevalence of $V$. parahemolyticus in the SF samples. $V$. alginolyticus was more likely in TB and SF than TMMC seals. $V$. cholerae (non-O1) and $V$. parahemolyticus were not detected in any samples from TB, but were isolated from stranded and SF seals. Salmonella was detected at a very low prevalence with the Newport serotype cultured from a single stranded seal and $S$. enteritidis from a single wild-caught seal. In addition to the targeted bacteria, several other enteric bacteria were cultured. Hemolytic E. coli, Pleisomonas shigelloides, and Edwardsiella tarda were detected in seals from all 3 locations. Beta-hemolytic Streptococcus, Streptococcus bovis, Klebsiella pneumonia, and Edwardsiella hoshinae were detected only at TMMC, and Photobacterium damsela was detected from a single seal in SF Bay.

Among the fecal cultures from stranded animals, a spatial-temporal cluster of Campylobacter isolates with a radius of $72 \mathrm{~km}$ was found centered in Santa Cruz (36 56' 53" N, $\left.122^{\circ} 3^{\prime} 57^{\prime \prime} \mathrm{W}\right)$ from April 17, 2008 to June 11, $2008(\mathrm{p}=0.010)$. Within this cluster, Campylobacter grew in 7 out of 12 fecal samples (Fig. 1). In addition, a purely temporal cluster of Campylobacter was found in seals stranding between 5 and 9 June 2008 when Campylobacter was cultured from 4 out of 5 fecal samples $(\mathrm{p}=$ 0.016): all 4 seals were weaned pups; 2 from Half Moon Bay Harbor and 2 from Moss Landing. Campylobacter isolates were not associated with proximity to the major outfalls and discharges $(p=0.423)$.

\section{Giardia and Cryptosporidium}

In 2006 and 2007, fecal samples from 40 stranded harbor seals (3 adults, 8 weaned pups, 29 pre-weaned pups) and 20 wild-caught harbor seals (8 adults, 6 subadults, 4 yearlings, 2 weaned pups) were tested by DFA for

a Vibrio spp. is the combination of $V$. cholerae, V. parahemolyticus,

and $V$. alginolyticus.

${ }^{\mathrm{b}}$ Not detected in any samples from Tomales Bay 
Giardia spp. cysts and Cryptosporidium spp. oocysts. There was 1 Cryptosporidium spp. positive from the feces of a weaned pup that stranded alive at Linda Mar Beach south of San Francisco Bay (373 $36^{\prime} 11^{\prime \prime}$ N, $122^{\circ} 29^{\prime} 56^{\prime \prime} \mathrm{W}$ ), and there was 1 Giardia spp. positive from the feces of wild-caught subadult captured in TB. Genotyping of parasites was not successful, likely due to the low number of fecal oocysts and cysts.

In 2008, fecal samples from 71 stranded harbor seals (4 adults, 1 subadult, 2 yearlings, 7 weaned pups, 54 pups) from 2007 and 2008 and 15 wildcaught seals (6 adults, 2 subadults, 3 yearlings, 4 weaned pups) from 2008 were tested at Wood's Hole Oceanographic Institute by PCR amplification of G. duodenalis DNA. There were 4 positives among the stranded seals and 1 positive among the wildcaught samples. As part of a survey of G. duodenalis molecular diversity, these positive samples were all identified as G. duodenalis Assemblage B (LasekNesselquist et al. 2010).

\section{Type A influenza}

A total of 107 harbor seals were sampled for influenza virus by PCR (Table 1). Rectal and nasal swabs from 96 wild-caught harbor seals (31 adults, 21 subadults, 9 yearlings, 35 weaned pups) and 11 preweaned pup carcasses from the mouth of Drakes Estero, Point Reyes National Seashore were negative for type A influenza using the matrix gene RT-PCR test ${ }_{i}$ however, virus isolation yielded a culture from the rectal swab of a female subadult captured in TB in June 2008. The viral isolate was initially characterized as an $\mathrm{H} 4$ hemagglutinin subtype by nucleotide sequencing. The presence of an influenza virus in the rectal swab could not be confirmed by 3 additional isolation attempts.

A subset of 92 serum samples from the seals tested by PCR were submitted for influenza serology (32 from SF and 60 from TB). Four of 36 (11\%) TB seals in 2007 and 2 of $24(8 \%)$ TB seals in 2008 had antibodies to avian influenza viruses. No positives were detected from seals sampled in SF, yielding an overall prevalence of $6.5 \%$ (6 out of 92) for all samples tested. The PCR-positive harbor seal was not seropositive.

\section{Brucella}

Tissues from 58 stranded harbor seals from 2007 and 2008 were submitted for Brucella screening: samples included 54 tracheobronchial lymph nodes, 55 spleens, 1 placenta, and 1 lung with accompanying lung worms. Age classes sampled were fetus $(\mathrm{n}=$ $1)$, premature pups $(n=15)$, full term pups $(n=30)$, weaned pups $(\mathrm{n}=11)$ and adult $(\mathrm{n}=1)$.

Two animals were Brucella-positive: one seal had a Brucella-positive spleen and lymph node. This seal had a bronchopneumonia associated with Otostrongylus circumlitis and liver lesions suggestive of sepsis, but no Brucella-associated pathology. A second seal had positive spleen, but negative lymph node, lung and lung worms Parafilaroides decorus. Lung worms were submitted because Brucellainfected $P$. decorus have been implicated as a possible source of infection in harbor seals (Garner et al. 1997). Intranuclear inclusions in the lung and adrenal consistent with phocid herpesvirus 1 and a pneumonia with Parafilaroides lung worms were observed in the second seal, but not Brucella-associated pathology. Both positives were detected in weaned pups, for an overall prevalence of $3 \%$ ( 2 out of 58 ), or a prevalence of $17 \%$ ( 2 out of 12 ) among the weaned pups and older age classes.

\section{Leptospira}

Serum samples from 263 harbor seals were submitted for the Leptospira MAT: 93 samples were from stranded seals and 170 samples were from wild seals. Among the stranded seals, the antibody titers were always highest for L interrogans serogroup Icterohemorrhagiae, and all titers were $\leq 1: 800$ except for 1 seal with antibody titers $>1: 3200$ to $L$. interrogans serogroup Icterohemorrhagiae and L. interrogans serovar Grippotyphosa. This yearling female was found dead on the beach. At necropsy, several areas of alopecia were noted around the eyes, anus and ventral surface of the flippers; there was a large abscess on the left hip, and severe bronchopneumonia. No lesions were seen in the kidneys, including the classic lesions seen with leptospirosis: interstitial nephritis and neutrophilic tubulitis. However, because of the high Leptospira titer, Steiner and Warthin Starry staining techniques (Luna 1968) were performed on the kidneys and no spirochetes were seen.

Among the wild-caught seals, antibody titers to $L$. interrogans serogroup Icterohemorrhagiae were the highest titer for all samples except for one adult male from TB that had a titer of 1:1600 to L. interrogans serovar Grippotyphosa and 1:100 to $L$. interrogans serogroup Icterohemorrhagiae. All other titers were 
low $(1: 100,1: 200,1: 400$, and one 1:800) and interpreted as evidence of exposure rather than infection. Prevalence of exposure varied by year, with Leptospira antibodies detected in almost all wild-caught harbor seals in 2004 and 2005 (Fig. 2).

\section{Toxoplasma gondii, Sarcocystis neurona, and Neospora caninum}

Serum samples were tested for protozoal exposure from 111 harbor seals admitted to TMMC. All stranded seals were pups except for 2 yearlings, 1 subadult, and 4 adults. One adult female that had antibody titers to $S$. neurona $(1: 10240)$ and $N$. caninum (1:320) had extensive meningoencephalitis, which is consistent with a Sarcocystis infection although no protozoa were evident on histologic examination, and immunohistochemistry (IHC) was not done. One subadult female with a titer to $T$. gondii (1:640) had severe bronchopneumonia, which was thought to be the cause of death. All stranded pups tested were negative for exposure to T. gondii, $S$. neurona and $N$. caninum (n=104).

Titers to all 3 protozoa were detected in sera from wild-caught seals from SF and TB (n=172, Table 1). One adult female sampled in SF had a titer to $T$. gondii of 1:10 240. She appeared healthy during capture, although there were hematological changes: lymphocytes, triglycerides, alkaline phosphatase, glucose, phosphorus, magnesium, total protein, and

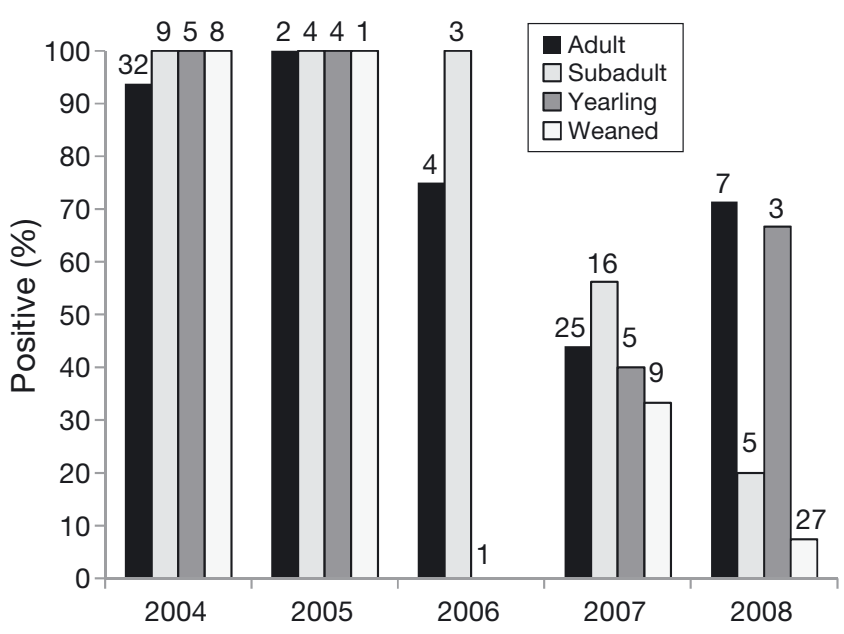

Fig. 2. Prevalence (percent positive) of wild-caught harbor seals with a titer to Leptospira interrogans serogroup Icterohemorrhagiae of 1:100 or greater by year. Sample size is indicated above each bar. Age classes are defined based on mass and time of year as weaned ( 4 wk to $1 \mathrm{yr})$, yearling (1 to 2 yr), subadult ( 2 yr to $45 \mathrm{~kg}$ ), adult ( $>45 \mathrm{~kg}$ ) after Bigg (1969) and Greig (2002) globulin were all elevated and her creatine kinase was decreased compared with other subadults and adults captured in May and June (Greig et al. 2010). She was observed for 9 mo after sampling and remained healthy in appearance. There was no difference between the seroprevalences of T. gondii and $S$.

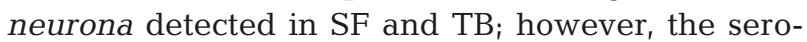
prevalence to $N$. caninum was higher in SF than TB (chi-square, $\mathrm{p}=0.007$ ).

\section{Morbillivirus}

A total of 326 serum samples were submitted for morbillivirus testing (109 from TMMC, 122 from SF, 95 from $\mathrm{TB}_{\text {; }}$ Table 1). All samples were negative for antibodies to CDV and PDV except for a single female weaned pup captured in TB in 2004, who had titers to CDV (1:256) and PDV (1:128). This was considered to be CDV positive with cross reaction to PDV (see 'Materials and methods').

\section{DISCUSSION}

This study demonstrates that exposure to a variety of pathogens, including zoonoses, occurs in harbor seals in central California. We detected differences between location in the prevalences of fecal bacteria cultured in wild-caught seals, and a spatial-temporal cluster of Campylobacter isolates in fecal samples from stranded seals. This is the first report of Sarcocystis neurona antibody prevalence in wild harbor seals, and the first survey for morbilliviruses and type A influenza in wild harbor seals in this region.

\section{Fecal bacteria}

Although Escherichia coli and Clostridium perfringens were more likely to be cultured in stranded harbor seals than in wild-caught seals, the high prevalence of these bacteria in all 3 groups, including apparently healthy seals, suggests that they are part of the normal intestinal flora of harbor seals. Vibrio spp. in the coastal environment vary by season and location, and their population dynamics are poorly understood (Thompson et al. 2005), thus patterns in seal exposure (i.e. increased prevalence in SF) may simply reflect differences in Vibrio distribution. A recent study of seals from the same locations as this study confirmed the variability of Vibrio prevalence in wild-caught versus stranded harbor seals (Hughes 
et al. 2013). Hughes et al. (2013) detected virulence genes in $V$. parahemolyticus isolates in these harbor seals and suggested that these bacteria have the potential to affect seal and human health.

The presence of Campylobacter is ephemeral in the marine environment (Stoddard et al. 2007), and strand date and location may be indicative of when and where the seal was exposed to the bacteria, although it is also possible that seals could be chronic carriers. In this study, seal exposure was associated with small boat harbors. While the Campylobacterpositive seals were not associated with known outfalls and sewage discharges, a more in-depth analysis of the variable flow rates at the discharge locations might be necessary to detect an association, as was done in a study of northern elephant seal Mirounga angustirostris infection (Stoddard et al. 2008).

The prevalence of Salmonella in stranded harbor seals $(1 \%)$ was much lower than that reported in stranded northern elephant seals $M$. angustirostris from the same region (36.9\%, Stoddard et al. 2005) although Newport, the most common serotype among the stranded elephant seals, was detected in a harbor seal. Among stranded seals in the United Kingdom, grey seals Halichoerus grypus also had a greater prevalence of Salmonella than harbor seals (Baker et al. 1995). Grey seals and northern elephant seals both remain on land from birth through their post-weaning fast, and may have increased exposure to fecal pollution from land compared with harbor seals which enter the water soon after birth.

While none of the fecal bacteria detected were associated with illness in the seals, they have the potential to contribute to enteritis and wound infections. The prevalence of Salmonella in infected wounds and tissues of stranded harbor seals during rehabilitation (5\%, Thornton et al. 1998) was greater than that detected in the feces of stranded seals at admission to rehabilitation $(0.7 \%$, this study). Plesiomonas shigelloides was associated with gastroenteritis among harbor seals pups that had been in rehabilitation for 1 to 3 mo (Koski \& Vandenbroek 1986) but was cultured in this study from 1 harbor seal admitted to rehabilitation and 3 clinically healthy wild harbor seal pups. The extent to which fecal bacteria are involved in the development of the septicemias and gastrointestinal disease observed in harbor seal pups in rehabilitation is unknown and beyond the scope of this study, but the fact that seals acquired potentially pathogenic bacteria, whether through their prey or directly from the environment, may be concerning for humans swimming or fishing in these same waters. For example, Photobacterium damsela, which we detected in 1 wild-caught seal in $\mathrm{SF}$, has caused fatal infections in fishermen (Yamane et al. 2004).

\section{Giardia and Cryptosporidium}

The prevalence of Giardia detected by this study (5 to $7 \%$ ) was less than that reported in Washington State harbor seals (42\%, Gaydos et al. 2008). This difference may be related to disease ecology or methodology: both this study and Gaydos et al. (2008) used the same immunofluorescence antibody test, although Gaydos et al. (2008) used immunomagnetic separation to concentrate Giardia by 1 or 2 logs in the fecal samples prior to analysis. Lasek-Nesselquist et al. (2010) detected a higher prevalence of Giardia in harbor seals on the east coast of the United States versus central California harbor seals using the same PCR primers for all samples. Thus, we suspect that the low number of detections in this study using DFA and PCR may reflect disease ecology influences, such as stronger tidal flushing of haulout areas in central California compared with Washington State. Many of the Washington State locations were in small inlets, while most of the stranded seals in this study came from locations along the open coastline or areas within SF with strong tidal flushing (Conomos et al. 1985).

\section{Type A influenza}

The identification of H4 influenza A virus from a rectal swab from an apparently healthy seal in 2008 suggests the virus was not pathogenic in this animal. Similarly, in 2010, the pandemic H1N1 influenza virus that circulated in humans in the US in 2009 was detected in apparently healthy wild-caught northern elephant seals (Goldstein et al. 2013). To date, isolation of influenza from stranded seals is rare in California, but seroprevalence varies by year and species, with higher levels of seroconversion in northern elephant seals than in harbor seals (Siembieda et al. 2008, Boyce et al. 2013, Goldstein et al. 2013). In contrast, influenza A infection of harbor seals along the Atlantic coast of the United States has resulted in significant mortality, most recently in 2011 due to H3N8 (Anthony et al. 2012).

While predominant in waterfowl infections with avian influenza, gastrointestinal involvement in influenza A infections are only occasionally reported in 
humans (Tamura et al. 2010); however, influenza RNA have been detected in stool samples up to $15 \mathrm{~d}$ after throat swabs were negative (Hu et al. 2013). In experimentally infected mice, some avian H1N1 virus variants show extended fecal shedding patterns, suggesting that influenza viruses in the feces may have a different transmission ecology from those in the lung (Koçer et al. 2013). We did not further characterize this virus as its presence could not be confirmed by additional isolation attempts from the original sample. However, H4N5, H4N6 as well as H3N3, H3N8, and H7N7 have been identified in harbor seals, suggesting that seals might act as a reservoir for influenza viruses, possibly allowing genetic reassortment and posing a potential risk to humans that work closely with these animals (Ohishi et al. 2002, Bodewes et al. 2013).

\section{Brucella}

Marine Brucella spp. have been shown to cause abortions in bottlenose dolphins Tursiops truncatus (Miller et al. 1999), but there is no histologic evidence from our study to implicate Brucella as a causative agent of disease in the stillborn or premature harbor seals that we sampled. Our Brucella-positive weaned pups are consistent with B. pinnipedialis culture, PCR, and serology data obtained from harbor seals in Washington State, which also detected the highest levels of exposure in weaned pups (Lambourn et al. 2013). Excluding the negatives from the pre-weaned pups, $17 \%$ prevalence in the post-weaning age classes is similar to the $11 \%$ reported in harbor seal tissue from the North Sea (Prenger-Berninghoff et al. 2008 ) and the $18 \%$ (5 out of 28) reported in weaned pups in rehabilitation in Washington State (Lambourn et al. 2013). These prevalences are worthy of consideration for humans in close contact with harbor seals (especially weaned pups), whether in rehabilitation or the wild, and among people who consume pinnipeds for food (Higgins 2000), as marine Brucella spp. can be transmitted through mucosal membranes (Brew et al. 1999).

\section{Leptospira}

The significance of the low Leptospira titers in the wild and stranded harbor seals is unknown, with only 1 stranded female yearling with a high titer suggesting active infection ( $>1: 3200$ to Grippotyphosa and Icterohemorrhagiae). This seal was dead when ad- mitted to TMMC, so it was not possible to submit paired titers for serology, and there were no Leptospira observed on histology.

The prevalence of low antibody titers $(\leq 1: 800)$ to $L$. interrogans serogroup Icterohemorrhagiae varied by year, and almost $100 \%$ of the wild harbor seals tested in 2004 and 2005 had titers, suggesting previous exposure to the bacteria. Among stranded California sea lions, which experience periodic outbreaks of leptospirosis caused by L. interrogans serovar Pomona, 2004 was a peak year for cases of leptospirosis (Lloyd-Smith et al. 2007). The Leptospira have recently been reclassified, and there is not agreement between serovar and genotype (Resch et al. 2007); therefore, without an isolate from a harbor seal it cannot be determined if the strain infecting harbor seals is the same or different from the strain isolated from sea lions. However, harbor seal exposure to Leptospira may be modulated by some of the same environmental drivers that affect cycles of leptospirosis in sea lions, or reflect the cycles observed in the sea lion population (Lloyd-Smith et al. 2007).

\section{Toxoplasma gondii, Sarcocystis neurona, and Neospora caninum}

This study is the first report of $S$. neurona antibody prevalence in wild-caught harbor seals. This protozoal genus has been of interest in harbor seals in central California because, from 1991 to 2001, 8 out of 9 instances where a protozoal infection was known to cause a harbor seal to strand were attributed to Sarcocystis sp. (Colegrove et al. 2005). The $3 \%$ prevalence of $N$. caninum that we detected in harbor seals in TB is similar to the $3.5 \%$ prevalence of $N$. caninum in harbor seals from Alaska (Dubey et al. 2003); however, we detected greater levels of exposure to this pathogen in the harbor seals in SF (12\%). The implications of the increased antibody titers to N. caninum in SF are unclear, and there are no documented cases of infection with this parasite in marine mammals, although there are cases of infection with an unrecognized protozoan (Dubey et al. 2003, Lapointe et al. 2003). The prevalence of $T$. gondii antibodies detected in wild-caught harbor seals in this study (7.6\%) was the same as detected in Washington State (Lambourn et al. 2001).

Transplacental infection with $T$. gondii has been reported in a sea otter and a bottlenose dolphin, and inconclusively in a harbor seal (Van Pelt \& Dietrich 1973, Dubey et al. 2003, Miller et al. 2008). Our negative results from the young pups in rehabilitation 
provide no evidence for transplacental transmission of this protozoal pathogen or antibodies against it. Serum was rarely obtainable from stillborn carcasses, however, and these protozoa cannot be ruled out as a cause of reproductive failure in harbor seals.

\section{Morbillivirus}

Since their identification in marine mammals, morbillivirus outbreaks have continued to have devastating consequences for seal populations. In 2002 for example, $14 \mathrm{yr}$ after the first outbreak, PDV was implicated in 22000 harbor seal deaths in the North Sea (Härkönen et al. 2006). Morbilliviruses have also been implicated in cetacean die-offs in the Mediterranean Sea, the Atlantic coast of North America, and the Gulf of Mexico (Di Guardo et al. 2005). Reports of morbillivirus in the north Pacific Ocean, however, have been rare. Reidarson et al. (1998) detected titers to dolphin morbillivirus in 6 of 18 common dolphins Delphinis delphis stranded in southern California, but characteristic morbilliviral lesions were not observed. Duignan et al. (1995) found no serologic evidence of morbillivirus in 80 harbor seals from the Pacific coast of North America, nor did Zarnke et al. (2006) in 286 harbor seals from Alaska. Recently, however, viral nucleic acid identical to an isolate from the 2002 PDV outbreak in the North Sea was reported in sea otters in Alaska (Goldstein et al. 2009). PDV remains undetected in harbor seals in California, but their naïve status puts them at risk from an epidemic. The canine distemper exposure detected in a harbor seal pup in TB could potentially have been from exposure to wild or domestic terrestrial animals. Coyotes Canis latrans are one possible vector. They have recently returned to Point Reyes National Seashore, which borders one side of Tomales Bay, and have been observed preying on harbor seal pups since 2004 (Vanderhoof \& Allen 2005).

There are advantages and disadvantages to a broad approach to pathogen surveillance involving different analytical methods and different sample sources. Because serology at a single time point cannot distinguish between current or previous exposure (Hall et al. 2010), and serology and isolation detect infection at different times, care must be taken when comparing prevalence data gathered by the 2 different approaches. In addition, not all tests are validated for use in harbor seals, making interpretation of results difficult. New techniques for pathogen detection, such as metagenomics, are finding novel pathogens from the tissues of sick animals ( $\mathrm{Ng}$ et al.
2009, Victoria et al. 2009), and are ideal for investigating disease outbreaks of unknown etiology. Microarrays can evaluate multiple nucleic acid sequences at once and also offer promise for pathogen screening.

Pathogen prevalence can vary with age class and, because there was very little overlap in age class between the wild-caught and stranded seals, prevalence rates could not be directly compared between these groups. The data do, however, provide insight into pathogen epidemiology. For example, the lack of exposure to Toxoplasma, Sarcocystis or Neospora in the young stranded seals and their prevalence in the wild-caught seals suggests that these pathogens are acquired later in life, or that the immature pup immune systems did not seroconvert. Another difficulty in comparing the data between stranded and wild-caught harbor seals occurs because the wildcaught seals are alive and usually clinically healthy. Exposure rate can be estimated, but it is not known how many seals were sickened or killed by the pathogen (i.e. only survivors are sampled).

In conclusion, while evidence of pathogen exposure was detected in seals of all ages, cases resulting in death were few, and there is little evidence that infectious diseases are major mortality factors for harbor seals in central California. One exception is infection with enteric bacteria which may not be a primary cause of disease, but can certainly compound the risk of mortality in debilitated seals. The second exception is morbillivirus, as the harbor seal population in California appears naïve unless harbor seals in the Pacific Ocean are less susceptible to morbilliviruses than other harbor seal populations. $S$. neurona continues to be implicated in stranding and death in adult harbor seals, and future work to understand this disease process is needed.

The presence of zoonotic pathogens, or evidence of exposure to them, in apparently healthy seals highlights the role these animals may play as reservoir species for zoonotic disease and the extent to which pathogens with terrestrial sources have invaded the marine environment. Harbor seals are useful sentinels and provide information about the risks to human and seal health from their shared environment. There are likely low risks to humans working with seals as long as standard protective measures are observed, but humans living and fishing in central California certainly could be exposed to the same pathogens as the seals.

Acknowledgements. We thank Tracey Goldstein, Erika Lasik-Nesselquist, Melissa Miller, Ann Melli, Stori Oates 
and staff and volunteers at The Marine Mammal Center, especially Tenaya Norris, Charlotte Jones, Amber Makie, Michelle Blascow, and Carlos Rios for advice and assistance with sample collection and analysis. We thank The John H. Prescott Marine Mammal Rescue Assistance Grant Program and Valentine Family Foundation for funding for this project. We thank Karina Acevedo-Whitehouse for thoughtful comments on the manuscript. Any use of trade, product or firm names is for descriptive purposes and does not imply endorsement by the US Government.

\section{LITERATURE CITED}

Anthony SJ, St. Leger JA, Pugliares K, Ip HS and others (2012) Emergence of fatal avian influenza in New England harbor seals. mBio 3:e00166-12

> Baker JR, Hall A, Hiby L, Munro R, Robinson I, Ross HM, Watkins JF (1995) Isolation of salmonellae from seals from UK waters. Vet Rec 136:471-472

Bigg MA (1969) The harbor seal in British Columbia. Bull Fish Res Board Can 172:1-33

> Bodewes R, Morick D, de Mutsert G, Osinga N and others (2013) Recurring influenza B virus infections in seals. Emerg Infect Dis 19:511-512

> Boyce WM, Mena I, Yochem PK, Gulland FMD and others (2013) Influenza A(H1N1)pdm09 virus infection in marine mammals in California. Emerg Microbes Infect 2:e40

Brew SD, Perrett LL, Stack JA, MacMillan AP, Staunton NJ (1999) Human exposure to Brucella recovered from a sea mammal. Vet Rec 144:483

> Brown JD, Stallknecht DE, Berghaus RD, Luttrell MP and others (2009) Evaluation of a commercial blocking enzyme-linked immunosorbent assay to detect avian influenza virus antibodies in multiple experimentally infected avian species. Clin Vaccine Immunol 16: 824-829

> Ciacci-Zanella JR, Vincent AL, Prickett JR, Zimmerman SM, Zimmerman JJ (2010) Detection of anti-influenza A nucleoprotein antibodies in pigs using a commercial influenza epitope-blocking enzyme-linked immunosorbent assay developed for avian species. J Vet Diagn Invest 22:3-9

Colagross-Schouten AM, Mazet JA, Gulland FM, Miller MA, Hietala S (2002) Diagnosis and seroprevalence of leptospirosis in California sea lions from coastal California. J Wildl Dis 38:7-17

> Cole JR Jr, Sulzer CR, Pursell AR (1973) Improved microtechnique for the leptospiral microscopic agglutination test. Appl Microbiol 25:976-980

> Colegrove KM, Greig DJ, Gulland FMD (2005) Causes of live strandings of elephant seals (Mirounga angustirostris) and pacific harbor seals (Phoca vitulina) along the central California coast, 1992-2001. Aquat Mamm $31: 1-10$

> Conomos TJ, Smith RE, Gartner JW (1985) Environmental setting of San Francisco Bay. Hydrobiologia 129:1-12

> Di Guardo G, Marruchella G, Agrimi U, Kennedy S (2005) Morbillivirus infections in aquatic mammals: a brief overview. J Vet Med Ser A 52:88-93

$>$ Dierauf LA, Dougherty SA, Lowenstine LJ (1986) Survival versus nonsurvival determinants for neonatal harbor seals. J Am Vet Med Assoc 189:1024-1028

> Dubey JP, Zarnke R, Thomas NJ, Wong SK and others (2003) Toxoplasma gondii, Neospora caninum, Sarcocystis neu- rona, and Sarcocystis canis-like infections in marine mammals. Vet Parasitol 116:275-296

> Duignan PJ, Saliki JT, St Aubin DJ, Early G and others (1995) Epizootiology of morbillivirus infection in North American harbor seals (Phoca vitulina) and gray seals (Halichoerus grypus). J Wildl Dis 31:491-501

Garner MM, Lambourn DM, Jeffries SJ, Hall PB and others (1997) Evidence of Brucella infection in Parafilaroides lungworms in a Pacific harbor seal (Phoca vitulina richardsi). J Vet Diagn Invest 9:298-303

Gaydos JK, Miller WA, Johnson C, Zornetzer H and others (2008) Novel and canine genotypes of Giardia duodenalis in harbor seals (Phoca vitulina richardsi). J Parasitol 94:1264-1268

Geraci JR, St Aubin DJ, Barker IK, Webster RG and others (1982) Mass mortality of harbor seals: pneumonia associated with influenza A virus. Science 215:1129-1131

Goldstein T, Mazet JAK, Gill VA, Doroff AM, Burek KA, Hammond JA (2009) Phocine distemper virus in northern sea otters in the Pacific Ocean, Alaska, USA. Emerg Infect Dis 15:925-927

- Goldstein T, Mena I, Anthony SJ, Medina R and others (2013) Pandemic H1N1 influenza isolated from freeranging northern elephant seals in 2010 off the central California coast. PLoS ONE 8:e62259

Greig DJ (2002) Pregnancy and parturition rates of harbor seals in Monterey Bay, CA. MS thesis, San Jose State University, Moss Landing, CA

Greig DJ, Gulland FMD, Rios CA, Hall AJ (2010) Hematology and serum chemistry in stranded and wild-caught harbor seals in central California: reference intervals, predictors of survival, and parameters affecting blood variables. J Wildl Dis 46:1172-1184

Grigg EK, Allen SG, Green DE, Markowitz H (2004) Harbor seal, Phoca vitulina richardii, population trends in the San Francisco Bay estuary, 1970-2002. Calif Fish Game 90:51-70

Gulland FMD, Hall AJ (2007) Is marine mammal health deteriorating? Trends in the global reporting of marine mammal disease. EcoHealth 4:135-150

Hall AJ, Gulland FMD, Hammond JA, Schwacke L (2010) Epidemiology, disease, and health assessment. In: Boyd IL, Bowen WD, Iverson SJ (eds) Marine mammal ecology and conservation. Oxford University Press, New York, NY, p 144-164

> Härkönen T, Dietz R, Reijnders P, Teilmann J and others (2006) The 1988 and 2002 phocine distemper virus epidemics in European harbour seals. Dis Aquat Org 68: $115-130$

> Heide-Jorgensen MP, Härkönen T, Dietz R, Thompson PM (1992) Retrospective of the 1988 European seal epizootic. Dis Aquat Org 13:37-62

> Higgins R (2000) Bacteria and fungi of marine mammals: a review. Can Vet J 41:105-116

> Hu Y, Lu S, Song Z, Wang W and others (2013) Association between adverse clinical outcome in human disease caused by novel influenza A H7N9 virus and sustained viral shedding and emergence of antiviral resistance. Lancet 381:2273-2279

> Hughes SN, Greig DJ, Miller WA, Byrne BA, Gulland FMD, Harvey JT (2013) Dynamics of Vibrio with virulence genes detected in Pacific harbor seals (Phoca vitulina richardii) off California: implications for marine mammal health. Microb Ecol 65:982-994

Ip HS, Flint PL, Franson JC, Dusek RJ and others (2008) 
Prevalence of Influenza A viruses in wild migratory birds in Alaska: patterns of variation in detection at a crossroads of intercontinental flyways. Virol J 5:71

Jeffries SJ, Brown BF, Harvey JT (1993) Techniques for capturing, handling and marking harbour seals. Aquat Mamm 19:21-25

> Jensen S, Aars J, Lydersen C, Kovacs K, Åsbakk K (2010) The prevalence of Toxoplasma gondii in polar bears and their marine mammal prey: Evidence for a marine transmission pathway? Polar Biol 33:599-606

Knap A, Dewailly E, Furgal C, Galvin J and others (2002) Indicators of ocean health and human health: developing a research and monitoring framework. Environ Health Perspect 110:839-845

Koçer ZA, Obenauer J, Zaraket H, Zhang J, Rehg JE, Russell CJ, Webster RG (2013) Fecal influenza in mammals: selection of novel variants. J Virol 87:11476-11486

Koski M, Vandenbroek DJ (1986) Plesiomonas shigelloidesassociated gastroenteritis in harbor seals (Phoca vitulina richardsi). In: Proceedings of the International Association for Aquatic Animal Medicine, 17th annual conference proceedings, Gulfport, MS, p 106-112

- Kulldorff M (1997) A spatial scan statistic. Comm Statist Theory Methods 26:1481-1496

Kulldorff M (2009) SaTScan ${ }^{\mathrm{TM}}$ v8.0: software for the spatial and space-time scan statistics. www.satscan.org (accessed on 17 Nov 2009)

Kulldorff M, Nagarwalla N (1995) Spatial disease clusters: detection and inference. Stat Med 14:799-810

> Lambourn DM, Jeffries SJ, Dubey JP (2001) Seroprevalence of Toxoplasma gondii in harbor seals (Phoca vitulina) in southern Puget Sound, Washington. J Parasitol 87: 1196-1197

Lambourn DM, Garner M, Ewalt D, Raverty S and others (2013) Brucella pinnipedialis infections in Pacific harbor seals (Phoca vitulina richardsi) from Washington State, USA. J Wildl Dis 49:802-815

> Lapointe JM, Duignan PJ, Marsh AE, Gulland FM and others (1998) Meningoencephalitis due to a Sarcocystis neurona-like protozoan in Pacific harbor seals (Phoca vitulina richardsi). J Parasitol 84:1184-1189

> Lapointe JM, Duignan PJ, Barr BC, Petrich AK, MacPherson DW, Gulland FM, Dubey JP (2003) Meningoencephalitis associated with an unidentified apicomplexan protozoan in a Pacific harbor seal. J Parasitol 89:859-862

> Lasek-Nesselquist E, Welch DM, Sogin ML (2010) The identification of a new Giardia duodenalis assemblage in marine vertebrates and a preliminary analysis of G. duodenalis population biology in marine systems. Int J Parasitol 40:1063-1074

> Lloyd-Smith JO, Greig DJ, Hietala S, Ghneim GS and others (2007) Cyclical changes in seroprevalence of leptospirosis in California sea lions: Endemic and epidemic disease in one host species? BMC Infect Dis 7:125

Luna LG (1968) Manual of histological staining methods of the Armed Forces Institute of Pathology, 3rd edn. McGraw-Hill, New York, NY

> Mamaev LV, Visser IK, Belikov SI, Denikina NN and others (1996) Canine distemper virus in Lake Baikal seals (Phoca sibirica). Vet Rec 138:437-439

> Miller WG, Adams LG, Ficht TA, Cheville NF and others (1999) Brucella-induced abortions and infection in bottlenose dolphins (Tursiops truncatus). J Zoo Wildl Med 30:100-110

Miller MA, Sverlow K, Crosbie PR, Barr BC and others
(2001) Isolation and characterization of two parasitic protozoa from a Pacific harbor seal (Phoca vitulina richardsi) with meningoencephalomyelitis. J Parasitol 87:816-822

Miller MA, Gardner IA, Packham A, Mazet JK and others (2002) Evaluation of an Indirect Fluorescent Antibody Test (IFAT) for demonstration of antibodies to Toxoplasma gondii in the sea otter (Enhydra lutris). J Parasitol 88:594-599

Miller M, Conrad P, James ER, Packham A and others (2008) Transplacental toxoplasmosis in a wild southern sea otter (Enhydra lutris nereis). Vet Parasitol 153:12-18

Morgan UM, Constantine CC, Forbes DA, Thompson RCA (1997) Differentiation between human and animal isolates of Cryptosporidium parvum using rDNA sequencing and direct PCR analysis. J Parasitol 83:825-830

Murray PR, Baron EJ, Jorgensen JH, Pfaller MA, Yolken RH (eds) (2003) Manual of clinical microbiology. ASM Press, Washington, DC

Ng TF, Suedmeyer WK, Wheeler E, Gulland F, Breitbart M (2009) Novel anellovirus discovered from a mortality event of captive California sea lions. J Gen Virol 90: 1256-1261

> Ohishi K, Ninomiya A, Kida H, Park CH and others (2002) Serological evidence of transmission of human influenza A and B viruses to Caspian seals (Phoca caspica). Microbiol Immunol 46:639-644

> Olson ME, Roach PD, Stabler M, Chan W (1997) Giardiasis in ringed seals from the western Arctic. J Wildl Dis 33: 646-648

Prenger-Berninghoff E, Siebert U, Stede M, König A, Weiß R, Baljer G (2008) Incidence of Brucella species in marine mammals of the German North Sea. Dis Aquat Org 81: $65-71$

R Development Core Team (2009) R: a language and environment for statistical computing. R Foundation for Statistical Computing, Vienna. www.r-project.org (accessed on 31 Dec 2009)

> Reidarson TH, McBain J, House C, King DP and others (1998) Morbillivirus infection in stranded common dolphins from the Pacific Ocean. J Wildl Dis 34:771-776

> Resch G, Awad-Masalmeh M, Bakoss P, Jarekova J (2007) Utility of phylogenetic studies in the identification of Leptospira strains. Epidemiol Infect 135:1266-1273

Ross PS (2000) Marine mammals as sentinels in ecological risk assessment. Hum Ecol Risk Assess 6:29-46

Saliki JT, Lehenbauer TW (2001) Monoclonal antibodybased competitive enzyme-linked immunosorbent assay for detection of morbillivirus antibody in marine mammal sera. J Clin Microbiol 39:1877-1881

> Sidor IF, Dunn JL, Tsongalis GJ, Carlson J, Frasca S Jr (2013) A multiplex real-time polymerase chain reaction assay with two internal controls for the detection of Brucella species in tissues, blood, and feces from marine mammals. J Vet Diagn Invest 25:72-81

- Siembieda J, Johnson CK, Boyce W, Sandrock C, Cardona C (2008) Risk for avian influenza virus exposure at humanwildlife interface. Emerg Infect Dis 14:1151-1153

Spackman E, Senne DA, Myers TJ, Bulaga LL and others (2002) Development of a real-time reverse transcriptase PCR assay for type A influenza virus and the avian H5 and $\mathrm{H7}$ hemagglutinin subtypes. J Clin Microbiol 40: 3256-3260

Stamper MA, Gulland FM, Spraker T (1998) Leptospirosis in rehabilitated Pacific harbor seals from California. J Wildl Dis 34:407-410 
Stevens E, Lipscomb TP, Gulland FM (1999) An additional case of leptospirosis in a harbor seal. J Wildl Dis 35:150

Stoddard RA, Gulland MD, Atwill ER, Lawrence J, Jang S, Conrad PA (2005) Salmonella and Campylobacter spp. in northern elephant seals, California. Emerg Infect Dis 11: 1967-1969

Stoddard RA, Miller WG, Foley JE, Lawrence J, Gulland FM, Conrad PA, Byrne BA (2007) Campylobacter insulaenigrae isolates from northern elephant seals (Mirounga angustirostris) in California. Appl Environ Microbiol 73:1729-1735

Stoddard RA, Atwill ER, Gulland FM, Miller MA and others (2008) Risk factors for infection with pathogenic and antimicrobial-resistant fecal bacteria in northern elephant seals in California. Public Health Rep 123:360-370

Tamura D, Fujino M, Ozawa M, Iwatsuki-Horimoto K and others (2010) Significance of seasonal influenza viruses in the stool of pediatric patients. Pediatr Infect Dis J 29: 578-579

Thompson JR, Pacocha S, Pharino C, Klepac-Ceraj V and others (2005) Genotypic diversity within a natural coastal bacterioplankton population. Science 307:1311-1313

Thornton SM, Nolan S, Gulland FM (1998) Bacterial isolates from California sea lions (Zalophus californianus), harbor

Editorial responsibility: Michael Moore, Woods Hole, Massachusetts, USA seals (Phoca vitulina), and northern elephant seals (Mirounga angustirostris) admitted to a rehabilitation center along the central California coast, 1994-1995. J Zoo Wildl Med 29:171-176

> Van Pelt RW, Dietrich RA (1973) Staphylococcal infection and toxoplasmosis in a young harbor seal. J Wildl Dis 9: 258-261

Vanderhoof M, Allen S (2005) Harbor seal monitoring at Point Reyes National Seashore and Golden Gate National Recreation Area. National Park Service Annual Report. Point Reyes Station, CA

Victoria JG, Kapoor A, Li L, Blinkova O and others (2009) Metagenomic analyses of viruses in stool samples from children with acute flaccid paralysis. J Virol 83: 4642-4651

Yamane K, Asato J, Kawade N, Takahashi H, Kimura B, Arakawa Y (2004) Two cases of fatal necrotizing fasciitis caused by Photobacterium damsela in Japan. J Clin Microbiol 42:1370-1372

Zarnke RL, Saliki JT, Macmillan AP, Brew SD and others (2006) Serologic survey for Brucella spp., phocid herpesvirus-1, phocid herpesvirus-2, and phocine distemper virus in harbor seals from Alaska, 1976-1999. J Wildl Dis 42:290-300

Submitted: December 29, 2013; Accepted: May 1, 2014

Proofs received from author(s): August 21, 2014 